\title{
SANITAIRE VERHOUDINGEN IN SURINAME ${ }^{1}$ ).
}

\author{
DOOR \\ PROF. P. C. FLU, te Leiden.
}

De bevolking van Suriname bestaat uit blanken, negers en indianen en de verschillende kruisingen dezer rassen en verder uit 26.000 Britsch-Indische en 11.000 Javaansche immigranten.

Het klimaat is tropisch. De hitte is overdag groot, maar de noordoost-passaat die krachtig, gedurende sommige jaargetijden zeer sterk waait, brengt een aangename afkoeling, welke vooral gedurende den avond en 's morgens vroeg, aangenaam aandoet.

Suriname is een regenrijk land. Op drie maanden na Augustus, September en October - regent het om zoo te zeggen altijd. Er valt jaarlijks gemiddeld 2300 m.M. regen, d.i. driemaal zooveel als in Nederland.

De sterfte bedraagt jaarlijks

$$
\begin{aligned}
& \text { voor Paramaribo ........18 per } 1000 \\
& \text {, geheel Suriname.... 20.25 , } 1000 .
\end{aligned}
$$

Vergelijkt men deze cijfers met die welke voor OostIndië bekend zijn, dan blijkt dat de sterftecijfers van Suriname bijzonder gunstig afsteken bij die van Insulinde.

Op Java, waar het Bestuur het best georganiseerd is, rekent men voor de landelijke bevolking een sterfte schommelend tusschen 20 en 25 per 1000 als normaal, Wel zijn er enkele districten met lager sterfte, van b.v. 14 per 1000 maar deze zijn uitzonderingen en daartegenover staan andere met 50 à 60 per 1000 sterfte en in verschillende groote steden aan de Noordkust van Java, Batavia, Semarang, Soerabaja, Probolingo, Cheribon en andere zijn er

1) Naar een voordracht voor de Indische week te Utrecht. 
stadsdeelen met een mortaliteit van 90 à 100 en zelfs van $120 \%$.

Vergelijken wij de lijst van ziekte- en doodsoorzaken van beide koloniën dan blijken Pest, Cholera en Pokken op die van Insulinde geregeld voortekomen, op die van de West steeds te ontbreken.

Beri Beri, een ziekte die in O.-Indië geregeld slachtoffers maakt is in West-Indië of onbekend of treedt slechts bij hooge uitzondering op.

Dysenterie en buiktyphus komen in beide koloniën als doodsoorzaken voor, hoewel de amoebendysenterie, welke het leverabsces doet ontstaan in West-Indië, in tegenstelling met Oost-Indië, hoogst zelden en dan alleen maar onder de landelijke bevolking voorkomt.

Malaria en de mijnwormziekte, de geesels van elke tropische bevolking zijn zoowel in Oost- als in West-Indië goede bekenden.

Ook bij deze vergelijking wint de West het van de Oost.

Er zijn echter twee ziekten welke op de West in ziektetopografisch opzicht een bepaalden stempel hebben gedrukt en wel; de gele koorts en de filariawormziekte.

De eerste is in Azië en dus ook in Nederlandsch-OostIndië onbekend, de tweede komt wel is waar over geheel Nederlandsch-Oost-Indië verbreid voor, maar voor zoover bekend, is ze slechts voor Sumatra van eenige beteekenis.

Daar de gele koorts de ziekte is welke schrik aanjaagt aan hen die over de West hooren spreken, zij het mij vergund wat nader op de beteekenis dezer ziekte voor WestIndië te wijzen.

$\mathrm{Zij}$ is voor Europeanen werkelijk verschrikkelijk, omdat zij in gele koortslanden alleen bij vreemdelingen doodelijk verloopt en onder de vreemdelingen zijn de Europeanen, over het algemeen de blanken, het gevoeligst. Noord-Europeanen zijn er gevoeliger voor dan Zuid-Europeanen en onder de eerste groep moeten vooral de blonden het ontgelden.

Toch is niet elke Europeaan die door de ziekte wordt aangetast onherroepelijk verloren. Het is toch bij de studie van de Epidemieën welke na 1900 opgetreden zijn her- 
haaldelijk gebleken,dat de meeste gevallen niet tot volle ontwikkeling komen, abortief verloopen, d.w.z. dat zich de ernstige verschijnselen van geelzucht, bloedbraken en nierlijden, welke den dood veroorzaken, niet openbaren. Slechts bij een betrekkelijk gering percentage der aangetasten is dit het geval. Zoo werden gedurende de epidemie welke van 1908-1909 te Paramaribo heesschte \pm 135 personen aangetast terwijl er slechts 14 stierven. In 1902 heerschte er ook een epidemie. Toen kende men de abortieve vormen nog niet. Men diagnostiseerde de ziekte alleen dan, wanneer zich de bovengenoemde ernstige verschijnselen openbaarden. Er stierf toen een grooter percentage der aangetasten maar in werkelijkheid was het aantal aangetasten grooter en daarom het percentage der dooden kleiner.

Sedert de onderzoekingen der Amerikanen op Cuba en na de successen welke zij en anderen bij de bestrijding en uitroeiing der ziekte mochten boeken, weten wij nu met zekerheid, dat de gele koorts wordt overgebracht door een kleine zwarte mug. Om dit te kunnen doen moet de mug zich eerst met het bloed van een gelekoortslijder hebben gevoed.

Men weet, dat de mug, de stegomyia fasciata, hare broedplaatsen kiest in de talrijke vergaarbakken, in welke de bevolking in tropische steden zonder centrale watervoorziening, het regenwater opvangt en bewaart. De muskiet verwijdert zich nooit ver van menschelijke woningen, is onder de muskieten evenals hare zuster, de gewone bruine culexmug een huisdier, maar dan een bijzonder ongewenscht en soms gevaarlijk huisdier.

De bestrijding, uitroeiing en voorkoming der gele koorts is buitengewoon eenvoudig. $\mathrm{Zij}$ bestaat in den aanleg van eene centrale drinkwatervoor ziening met distributie van het water door middel van gesloten leidingen tot aan en in de woningen; in het uitvaardigen van een verbod waterreservoirs in en bij huis te hebben en in het organiseeren van een eenvoudigen dienst welke zorgt dat het verbod wordt nageleefd.

Niettegenstaande, dit alles reeds lang bekend is, zijn 
toch de verantwoordelijke autoriteiten ingebreke gebleven en zijn zij nooit met kracht en energie opgekomen voor aanleg en exploitatie van eene drinkwaterleiding te Paramaribo.

Toch is een dergelijke waterleiding voor enkele in de West gelegen steden, in het bijzonder voor Paramaribo, de hoofdstad van Suriname, van buitengewoon groot belang.

De bevolking dezer stad bedraagt ongeveer 40.000 zielen en is zeer sterk geïnfecteerd met een parasiet, een worm, de filariaworm waardoor de filaria-wormziekte veroorzaakt wordt, welker bestrijding zonder centrale drinkwatervoorziening onmogelijk is.

Het parasitisme van den filariaworm, de Filaria bancrofti, voert tot ziektetoestanden waaraan wel is waar de aangetasten niet in grooten getale te gronde gaan, maar die, wat misschien in sociaal-eoconomisch opzicht nog bedenkelijker is, de lijders tot invalieden en tot non valeurs maakt.

De Filaria bancrofti behoort tot de zgn. rondwormen. De wijfjes worden 12 m.M. de mannetjes 5 m.M. lang en beiden zijn zoo dun als een haar. Zij leven in de groote lymphe- of watervaten van ons lichaam en kunnen tengevolge van het groote aantal waarin zij voorkomen tot verstopping der lymphevaten en als gevolg hieıvan tot allerlei ziektetoestanden voeren.

Het wijfje brengt levende larven voort welke door den Iymphestroom medegevoerd in de algemeene circulatie terecht komen en in het bloedvatenstelsel blijven circuleeren. Merkwaardig, met het oog op de overbrenging van de larven door een bij nacht stekend insect, is het verschijnsel dat men de larven alleen gedurende de avonduren in eenigszins belangrijk aantal aantreft in het bloed, dat men oorlel of vingertop ontneemt. Tegen middernacht is hun aantal het grootst en tegen den morgen verdwijnen zij weer.

Patrick Manson, aan wien wij zooveel van onze kennis omtrent de filariawormziekte te danken hebben, kon door een gelukkigen samenloopvan omstandigheden aantoonen dat de larven zich gedurende den dag naar de inwendige 
organen van den lijder, in hoofdzaak naar de longen, terug trekken.

Dezelfde Manson heeft ook ontdekt dat de larven van den filariaworm door muggen van den een op den ander worden overgebracht. Hij kon reeds in 1877 aantoonen, dat bepaalde muskieten als overbrengsters dienst doen. Zoowel de gewone bruine kamermug, de Culex fatigans en pipiens alsook de in tropische gewesten zeer verbreid voorkomende gelekoorts mug, de Stegomyia fasciata zijn daartoe in staat.

De larven geraken met het opgezogen bloed in de muggenmaag, doorboren den maagwand en komen tenslotte in de borstspieren van de mug terecht. Daar maken zij een ontwikkelingsproces door, dat na 12-14 dagen voltooid is. Zij verlaten dan de borstspieren en komen terecht in de holte van een buis, de zgn. zuigscheede, welke de steek- en snijorganen van de mug omgeeft.

Steekt de mug dan dringt de ,zuigscheede” het lichaam niet binnen, maar wordt geknikt. Haar inhoud komt onder spanning en een dun vliesje, waarmede het op de huid rustend einde van de zuigscheede is afgesloten, scheurt. De larven ontsnappen door dit scheurtje en komen op de huid van den gestokene terecht. $Z$ ij kunnen nu, hetzij door de steekopening, hetzij door de openingen van zweeten smeerkliertjes de buid binnendringen en vervolgens hun weg naar de bloed- en lymphevaten vinden.

Patrick Manson had, toen hij zijne ontdekking deed, zooals trouwens al zijn tijdgenooten, verkeerde voorstellingen over den levensduur van muggen. Men meende algemeen, dat muggen diertjes met een heel kort leven waren. Vooral de wijfjes zouden reeds 8 dagen nadat zij het poppenstadium hadden verlaten bij het eierleggen in hetwater vallen en dood gaan. De larven zouden dan, zoo meende Manson, het muggenlichaam verlaten en in het water terechtkomen. Het drinken van met larven geïnfecteerd water zou dan tot besmetting kunnen voeren.

Later leerde men inzien, dat muggen betrekkelijk lang leven. Een mug kan in gevangenschap wel drie maanden 
en soms nog langer leven, terwijl vrij vliegende muggen gemiddeld 60 dagen leven.

Afgezien van de talrijke feiten welke tegen de oorspronkelijke opvatting van Manson pleiten, hebben talrijke proefnemingen absoluut zeker aangetoond dat de overbrenging bij en door den steek van de geïnfecteerde muskiet geschiedt. Zoowel in Italië, door Grassi en Noé, als in Engeland door Manson zelf en in Duitschland door Fülleborn is overtuigend bewezen, dat muggen in staat zijn door hun steek de infectie met den filariaworm overtebrengen.

Het onderzoek heeft nu verder de volgende, voor de kennis van de verbreidingswijze en voor een doelmatige bestrijding en voorkoming der ziekte belangrijke feiten aan het licht gebracht.

In een land waar filaria bancrofti voorkomt vertoonen lang niet alle personen in wier bloed men de larven aantreft ziekteverschijnselen. Integendeel, hoe paradoxaal het ook moge klinken, het is een goed geconstateerd feit, dat de normale toestand van den drager van filaria bancrofti die is, dat hij zonder verschijnselen is.

In een filarialand kunnen dus personen, die nooit eenig verschijnsel van de ziekte hebben vertoond toch aan hare verspreiding medehelpen.

Verder is gebleken, dat de infectie niet gemakkelijk aanslaat. In de eerste plaats worden niet alle muggen die zich met filariahoudend bloed voeden zoo sterk geïnfecteerd dat zij uitgegroeide larven in de zuigscheede vertoonen. Dan veroorzaakt niet elke geïnfecteerde stekende mug een infectie. Steekt een geïnfecteerde muskiet door kleedingstukken, dan blijven de larven welke de zuigscheede - die toch niet in de huid dringt - verlaten op de kleedingstukken. Tenslotte verongelukken een groot aantal larven op hun weg van de huid naar de groote lymphevaten.

Men weet dan ook, dat voor een belangrijke verbreiding - zooals zij helaas te Paramaribo bestaat - verschillende factoren moeten medewerken, o.a. een bijzonder groot aantal muggen, een groot aantal personen met veel larven in het bloed, die samen met andere niet of matig 
geïnfecteerden hetzelfde huis of dezelfde kamer bewonen, terwijl bovendien dit samenwonen niet kort maar lang moet duren.

Beschouwen wij met deze kennis toegerust, de verbreiding van de filariose onder de bevolking van Paramaribo, dan zien wij zooals mij bleek bij een onderzoek dat ik van 1908-1910 instelde, dat ongeveer 50 à $60 \%$ van de arme bevolkingsklassen en $23-25 \%$ van de sociaal iets meer bevoorrechten zijn geïnfecteerd.

De Europeanen, die wel is waar geen afzonderlijke wijken bewonen, maar toch - indien men let op den vliegafstand der muggen - op betrekkelijk grooten afstand der zoo sterk geïnfecteerde armere bevolkingsklassen wonen, vertoonen reeds een infectiecijfer van $1.2 \%$. Dat ditgeringe infectiecijfer niet mag worden toegeschreven aan de betere hygienische verhoudingen waaronder de meeste Europeanen te Paramaribo verkeeren, blijkt reeds hieruit, dat de zeer onhygiënisch levende Britsch-Indische immigranten, die meestal buiten Paramaribo, dus nog verder dan de Europeanen van de geïnfecteerde arme stadsbevolking wonen een infectiecijfer van $0.7 \%$ vertoonden.

In 1911 schreef ik reeds:

„Onderzoekt men waarom de lagere volksklassen een zoo enorm hoog infectiecijfer vertoonen, dan vindt men dat vele factoren hiervan de oorzaak zijn.

Vooreerst is dit deel der bevolking sessiel. Over het algemeen kan men zeggen, dat de kans drager van filaria te zijn des te grooter wordt, naar mate men langer in een filariastreek vertoeft. Zonder meer is het dus duidelijk, dat Surinamers de meeste kans hebben geïnfecteerd te worden. Vooral echter moet de oorzaak van dit prevaleeren onder de inheemsche bevolking worden gezocht in hun woon- en leefwijze, die maar te dikwijls erg primitief is.

In de stad Paramaribo, bevinden zich als een overblijfsel uit den slaventijd, op de vrij groote erven der heerenhuizen rijen kamers, zgn. negerwoningen. Het is niet zeldzaam, dat er 30 en meer van zulke negerwoningen op een erf, heel dikwijls dicht bij het hoofdgebouw zich bevinden. Vroeger waren deze woningen het verblijf der sla- 
ven, die het eigendom der hoofdbewoners waren. Thans wonen er de dienstboden, terwijl dat deel der woningen dat niet door hen betrokken is, verhuurd wordt aan het volk tegen een geringe maandelijksche huur. Erven met 50 en meer bewoners zijn niet zeldzaam.

Zulk een rij van negerwoningen bestaat meestal uit een rechthoekige loods. De vloer ligt op enkele d.M. boven den grond en de planken waaruit hij bestaat, liggen soms een centimeter van elkaar af. Door de hierdoor gevormde reten verzamelt zich steeds zand, dat natuurlijk droog blijft en dus een geschikte verblijfplaats voor de zandvloo, vormt.

Tusschenschotten, die veelal niet tot het dak reiken, verdeelen deze loods in kamertjes van $4 \times 5 \mathrm{M}$. oppervlak. Een plafond schut een klein dakkamertje af dat meestal tot slaapvertrek wordt benut. In zulke kamertjes slapen niet zelden 8 à 10 menschen. De gewoonte van het volk om zonder meer bij hunne familie of vrienden uit logeeren te gaan,maakt het aantal bewoners dikwijls nog grooter.

Paramaribo is niet in het bezit van eene centrale watervoorziening. Regenwater dat van de daken wordt verzameld en wordt bewaard in reservoirs wordt als drinkwater gebruikt. Nu bestaan er geen wetten die aan den hoofdbewoner of eigenaar voorschrijven voor een voldoend groot reservoir te zorgen. Op vele erven, men kan zeggen bijna op alle, moet elk der bewoners van de negerwoningen maar zelf trachten voldoende regenwater te verzamelen. Goed afgesloten tanks zijn heel duur en het volk gebruikt als reservoirs houten vaten, ijzeren en zinken bakken en vrijwel elk soort reservoir dat zich maar aanbiedt. Deze reservoirs staan dicht bij het huis. Een primitieve dakgoot leidt het dakwater naar de reservoirs en daar deze onvoldoende tegen muggenbezoek beschermd zijn, wemelt het in hun water evenals in dat hetwelk in de dakgoten na regens blijft staan van larven van culex en stegomyia.

Binnen de woningen, in de donkere, door velen bewoonde slaapruimten vinden de volwassen muggen steeds volop bloed en het is duidelijk, dat men op deze wijze ware culturen van muggen aanlegt. 
De bevolking schijnt er, hoewel onbewust, steeds op uit te zijn, de muggen het broeden zoo makkelijk mogelijk te maken. Daar waar er door een groot reservoir van het hoofdgebouw voor voldoend drinkwater gezorgd is, hebben zij toch watervaten. Deze de zgn. „aschvaten” zijn voor de helft met asch en verder met water gevuld. De asch wordt uitgeloogd en het water wordt zeer geschikt voor het wasschen van kleedingstukken."

$\mathrm{Na}$ deze korte uitweiding zal het duidelijk zijn, dat het veelvuldig voorkomen van filariën onder de inheemsche stadsbevolking, niet met het ras der bewoners in verband staat, maar wel met de treurige toestanden op het gebied der drinkwatervoorziening.

De beteekenis van de filariawormziekte is voor Paramaribo's bevolking daarom zoo funest omdat zij een groot deel der bevolking tot invalieden maakt. Men overdrijft stellig niet door te zeggen dat $\frac{1}{4}$ deel van Paramaribo's bevolking gebukt gaat, en dit wel gedurende de anders meest krachtige en productieve levensperiode (30-40e jaar) aan een of meer der gevolgen van de filaria-infectie.

De ziektevormen en verschijnselen welke met het parasitisme van de filaria bancrofti in verband staan zijn talrijk en wisselend.

Het meest gevreesd zijn aanvallen van een op wondroos gelijkende ontsteking der huid. Meestal wordt de huid der onderste ledematen aangetast, maar elk ander lichaamsdeel kan meedoen. Deze zgn. „boeboe” aanvallen zijn de schrik der bevolking. Zij beginnen met eene koude rilling en heftig braken, gevolgd door hooge temperatuur en pijn in de ontstoken lichaamsdeelen. De lijder is na zulke aanvallen gedurende minstens een week aan zijn bed gekluisterd. De aanvallen kunnen zich soms wekelijks of maandelijks herhalen.

De herhaalde boeboeaanvallen voeren tenslotte tot eene verdikking van de huid, welke weer aanleiding geeft tot eene wanstaltige vervorming van de aangetaste lichaamsdeelen tot de zgn. oliefantspootvorming, de elephantiasis arabum, de matabimba der inheemsche bevolking. 
Wel meer dan $40 \%$ der bevolking van Paramaribo lijdt aan elephantiasis, zij het dan ook dat de wanstaltige vervorming der onderste ledematen niet steeds evenveel hinder bij het loopen veroorzaakt.

Behalve de zoo juist genoemde verschijnselen ziet men nog veelvuldig sterk gezwollen klieren in de liesstreken of raken vooral de watervaten aan de binnenvlakte der dijen sterk uitgezet.

Een ernstige ziekte is de lymphefistel. Deze ontstaat wanneer een dicht onder de huid liggend, uitgezet watervat op de een of andere wijze wordt verwond. Een betrekkelijk gering geweld is hiertoe soms voldoende. De lymphe druppelt dan door de kleine opening voortdurend af en het groote verlies van het voor het lichaam onmisbare vocht veroorzaakt niet alleen lichaamszwakte, maar de opening in het vat stelt den lijder aan het gevaar van een doodelijke etterinfectie bloot.

Ernstige beteekenis voor de gezondheid heeft ook het „melkbloedwateren", de haemato-chylurie. De patient heeft hierbij aanvallen van koorts waarbij in plaats van, of gemengd met urine een melkwitte soms ook kersroode troebele massa door de pisbuis wordt geloosd. Het lijden voert tot verzwakking soms ook tot den dood der lijders.

$\mathrm{Nu}$ wij den verwekker van de filariasis kennen; weten dat de filariaworm door den steek van met die filaria geinfecteerde muskieten wordt overgebracht en precies ingelicht zijn over de leefwijze van de muskieten welke de rol van overbrengsters spelen, is het niet moeilijk precies aantegeven hoe men de ziekte heeft te bestrijden en wat meer zegt hoe men haar met absolute zekerheid kan voorkomen.

Men geve Paramaribo eene centrale watervoorziening, waarbij van uit het hoofdreservoir het water door middel van gesloten leidingen tot in of tot dicht bij de woningen wordt gebracht; men vaardige direct na het tot stand komen der waterleiding en huisaansluiting een verbod uit om in of bij huis broedplaatsen van muggen te scheppen en men organiseere een eenvoudige dienst ter scherpe controle op 
de naleving der bepalingen en men zal reeds enkele jaren later een belangrijke daling in de ziektecijfers voor zoover betreft de verschijnselen der filariasis zien intreden.

Daar de filaria dikwijls onherstelbare veranderingen veroorzaakt zal men natuurlijk geen genezing van reeds bestaande ziektevormen zien plaatsvinden. Een elephantiasis zal niet genezen, ook zal iemand met melkbloedwateren nog steeds blijven bloedwateren, maar nieuwe infectie's zullen niet optreden en het komende geslacht en reeds de jeugd zal van nieuwe infectie's worden gevrijwaard.

Juist omdat het effect der bestrijding zoo lang op zich zal laten wachten is het een gebiedende eisch om - wil men werkelijk ernstig gemeende hulp aan Paramaribo's bevolking bieden - zoo snel mogelijk Paramaribo eene waterleiding te bezorgen.

Het werk van de Amerikanen te Panama en Colombo heeft bewezen dat het praktisch mogelijk is om in tropische steden, waar de plaatselijke verhoudingen niet veel van die van Paramaribo verschillen met succes een strijd tegen culex en stegomyia te voeren. De Amerikanen verrichtten aldaar pioniersarbeid welke hun schatten kostte; wij die van de ervaring door hen opgedaan kunnen profiteeren kunnen met betrekkelijk geringe middelen hetzelfde bereiken.

Ik kom, nadat ik enkele ziekten van de landelijke bevolking besproken zal hebben op de kwestie der drinkwatervoorziening terug.

Evenals in alle andere waterrijke tropische landen heeft ook in Suriname de malaria een groote beteekenis als volksziekte. $\mathrm{Zij}$ treedt in het kustgebied onder alle drie bekende vormen op en wel als anderdaagsche (Tertiana) derdendaagsche (Quartana) en tropische (perniciosa). De meeste gevallen behooren tot het tertiana-type en de infectie's met tertiana zijn voor het leven der aangetasten niet zoo gevaarlijk als degevaarlijke tropica-infectie's, welke vooral in het door Boschnegers en Indianen bewoonde binnenland optreden. 
Malaria is een ziekte van de landelijke bevolking en in overeenstemming daarmede zien wij dan ook dat de bevolking van de stad Paramaribo, voor zooverre zij niet leeft in eene omgeving met een landelijk karakter niet of bijna niet onder de malaria te lijden heeft.

Wel komt malaria voor onder de bewoners der buitenwijken en landerijen om de stad.

De bevolking der langs de rivieren liggende plantages en nederzettingen gaat dikwijls zwaar gebukt onder malaria en hare gevolgen. Malaria is op die plantages en nederzettingen een chronische ziekte, die tot invaliditeit der aangetasten voert. Voor ondernemingen die met dure geimporteerde arbeiders moeten werken, wier winstmarge bovendien tengevolge van ziekte onder de cultuurgewassen niet breed is, heeft dus de malaria een buitengewoon groote economische beteekenis.

Het is bekend dat malaria door den steek van met malariaparasieten geïnfecteerde muggen wordt overgebracht en de onderzoekingen der laatste jaren hebben op steeds meer overtuigende manier aan het licht gebracht, dat lang niet alle anophelesmuggen in dit opzicht dezelfde beteekenis hebben. Terwijl sommige soorten onder natuurlijke verhoudingen malaria buitengewoon gemakkelijk overbrengen zijn andere soorten daartoe niet in staat. De wijze van verbreiding en van het ontstaan en het beloop der epidemieën houdt nauw verband met factoren welke vooral van invloed zijn op het aantal, de wijze van broeden, de maximale vliegafstand der muggen enz.

In Suriname is, zooals bijna voor geheel tropisch Amerika, de Anopheles s. Cellia albimanus s. argyrotarsus de voornaamste malariaoverbrengster, en het treft voor de malariabestrijding in Suriname bijzonder ongelukkig dat deze mug gebruiken heeft welke dien strijd buitengewoon moeilijk maken.

De Cellia albimanus broedt zoowat in alle plassen, mits hun water niet dieper dan $0.5 \mathrm{M}$. is en niet stinkt; in het waterrijke kustgebied van Suriname dus zoowat overal. $\mathrm{Zij}$ is bovendien in staat om groote afstanden 1500-3000 M. van en naar hare broedplaatsen afteleggen, is zeer 
bloeddorstig en tot een hoog percentage zoowel onder natuurlijke als onder kunstmatige verhoudingen met malaria te infecteeren.

$\mathrm{Nu}$ bestaat de beste, op den duur meest effectieve, meest rationeele en economische malariabestrijding in het verwijderen of ongeschikt maken der broedplaatsen van de overbrengende muggen. Men bereikt dit op de meest afdoende manier door drooglegging, drainage der broedplaatsen. Drainage, in een heuvelland betrekkelijk eenvoudig, is in lage moerassige streken alleen mogelijk indien men over ruime middelen beschikken kan - en Suriname is arm.

Op de ondernemingen zullen de planters zich maar kunnen bepalen tot het verwijderen van broedgelegenheden welke zich in de onmiddellijke nabijheid der woningen bevinden en hoewel moet worden toegegeven dat een dergelijke maatregel, mits goed en systematisch uitgevoerd, een gunstigen invloed op de malariaziektecijfers hebben kan, behoeft men zich geen illusies te maken op deze manier malaria te bestrijden.

Een ander bestrijdingsmiddel bestaat in de bescherming der huizen met muggengaas. Dit middel heeft echter alleen dan succes indien de te beschermen personen volkomen op de hoogte en overtuigd zijn van de juistheid der leer, dat malaria door muskieten wordt overgebracht. Van de onontwikkelde arbeidersbevolking, die toch in de eerste plaats moet worden beschermd kan men dit alles niet verwachten en daarom ware het dwaasheid indien men die bevolking mechanisch tegen malaria zou willen beschermen.

Een derde middel bestaat in het prophylactisch toedienen van chinine. In landen zooals o.a Italië, waar het koortsseizoen maar enkele maanden duurt is deze methode op groote schaal en met succes toegepast. In zulke landen kan men gedurende het koortsvrije seizoen de toediening van chinine staken en hebben de te beschermen personen gelegenheid om uitterusten.

In een tropisch land, waar zooals in Suriname de infectiemogelijkheid het geheele jaar bestaat zou men de chi- 
nine dag in dag uit en jaar op jaar moeten blijven verstrekken en zooiets is praktisch op groote schaal absoluut onuitvoerbaar.

Wat nu, moet men dan maar de malaria haar gang laten gaan en voortgaan met zooals nu geschiedt niets ter harer bestrijding te doen?

Ik vrees dat men, gelet op de organisatie van den medischen dienst in de landbouwende districten van Suriname niets zal kunnen doen. Ware de organisatie anders dan zou men door het geregeld bijhouden van ziekte en sterftestaten van alle op de ondernemingen levende personen, spoedig elke abnormale verhooging van het ziekte- en sterftecijfer bemerken en na een ingesteld onderzoek, zich vormende malariahaarden kunnen ontdekken. De bevolking in en om zulke haarden zou men dan zoolang moeten chininiseeren tot het gevaar geweken was.

In elk geval biedt de bestrijding van malaria zoowel in het lage kustgebied als in het heuvelachtige binnenland van Suriname moeilijkheden welke door de medische dienst in zijn huidige organisatie niet uit den weg te ruimen zijn. Voor zoover het kustgebied daarbij betrokken is, zal aan een doelmatige malariabestrijding eene reorganisatie van de medische koelieverzorging moeten voorafgaan.

Een andere, vooral voor de landbouwende bevolking zeer ernstige volksziekte is de mijnworm- of ankylostomaziekte.

Ankylostomen zijn kleine \pm 13 m.M. lange wormen welke zich met hun scherpe mondranden aan het darmslijmvlies vasthaken. Zij verwonden hierbij bloedvaten en geven aanleiding tot het ontstaan van bloedarmoede bij de aangetasten.

De bloedarmoede welke soms belangrijk kan zijn voert tot vermindering en tenslotte tot geheele vernietiging van de werkkracht der arbeiders. De ziekte heeft dan ook een buitengewoon groote economische beteekenis voor de planters en verdient de volle aandacht van plantagebezitters.

De wormen leggen eieren welke met de ontlasting het 
lichaam der lijders verlaten. Voor hun verderen groei en ontwikkeling hebben zij zuurstof, een zekere graad van vochtigheid en een temperatuur van $25-30^{\circ} \mathrm{C}$. noodig. Daar al deze factoren in de tropen aanwezig zijn verloopt de ontwikkeling snel en reeds na 10-14 dagen zijn de larven in staat tot nieuwe infectie's te voeren. Vroeger meende men, dat zij hiertoe door het slachtoffer moesten worden doorgeslikt, maar sedert de onderzoekingen van Loos, waarvan de resultaten alom werden bevestigd, weet men dat de volwassen larven zoodra zij met de huid in aanraking komen - wat bij de blootsvoets loopende koelie's geregeld geschiedt - door de zweet- en smeerkliertjes het lichaam binnendringèn. Door het bloed worden zij dan naar de longen gevoerd. Zij doorboren de longblaasjes en worden door de wimperbeweging van het bekleedsel der luchtpijpvertakkingen, naar het strottenhoofd en de keelholte gevoerd. Doorgeslikt komen zij door de maag naar de darmen, waar zij zich aan het darmslijmvlies vasthechten en reeds zes weken later volwassen zijn.

De bestrijding der ziekte schijnt zeer eenvoudig; men heeft slechts voor goede privaten en een doelmatige vernietiging der in het privaat verzamelde faeces te zorgen om de ziekte met zekerheid te voorkomen.

Jammer is, dat men met dit eenvoudig schijnend middel niets bereikt bij de primitieve, op hygiënisch laag peil staande arbeidersbevolking. Zij gebruikt het privaat of in het geheel niet of de arbeiders blijven behalve in, ook buiten het privaat defaeceeren.

Waar men zelfs onder de op belangrijk hooger peil staande Nederlandsche mijnwerkers alsook bij de onder strenge discipline staande Duitsche met het aanleggen van privaten alleen geen succes had, is scepticisme tegenover dit bestrijdingsmiddel van de ankylostomiasis onder een tropische landbouwende bevolking volkomen gerechtvaardigd.

Natuurlijk zal men zooveel mogelijk privaten bouwen, maar daarnaast zal men door systematisch toegepaste wormkuren de infectiegraad der bevolking onder een zeker minimum moeten brengen en houden. 
De tropenhygiëne heeft juist bij de bestrijding der mijnwormziekte schitterende successen geboekt, maar voor de bereiking van blijvende resultaten is goede organisatie een hoofdvoorwaarde.

$\mathrm{Ik}$ heb in het voorgaande de ziekten, die eene gezonde ontwikkeling der bevolking in den weg staan aan eene meer uitvoerige bespreking onderworpen, omdat zij bij eene eventueele assaineering van het land het eerst en het krachtigst moeten worden bestreden, niet omdat zij de eenige ziekten zijn welke onze aandacht verdienen.

Tuberculose en wel longtuberculose komt onder de sterfteoorzaken van alle West-Indische koloniën voor en wel met 10-14\% der totale sterfte, cijfers welke wij b.v. ook in Nederland aantreffen.

De kindersterfte is vooral onder de stedelijke bevolking der verschillende koloniën belangrijk, terwijl geslachtsziekten als oorzaken van mis- en vroeggeboorten, als veroorzakers van steriliteit en invaliditeit eene belangrijke beteekenis hebben.

Een hygiënist die geroepen wordt om in de zoo juist gesignaleerde wantoestanden verbetering te brengen heeft keuze en werk genoeg.

Is hij met de plaatselijke toestanden, met aard en gebruiken der bevolking bekend, dan zal hij, terwijl hij aan tuberculosebestrijding, kinderzorg en bestrijding der geslachtsziekten zijn aandacht schenken zal, zich met alle kracht werpen in den strijd tegen die ziekten welke wij als de voornaamste belagers der volkskracht in de koloniën hebben leeren kennen, nl. de filariasis, de mijnwormziekte en de malaria.

Bestrijding van tuberculose, en geslachtsziekten, zorg voor kraamvrouwen en zuigelingen is sociaal hygiënisch werk. Men bereikt hierbij zonder de medewer king van alle medici en de bevolking niets. Men moet de bevolking in hygiënischen zin opvoeden, enz. Dit alles is niet eenvoudig en eerst na veel geduld en met veel tact kan men tot eene organisatie komen, die voor de toekomst iets belooft. 
Anders staat de hygiënist tegenover de filariasis, aan den eenen, de malaria, ankylostomiasis en andere zgn. koelieziekten aan den anderen kant. Tegen die ziekten kan hij met kracht optreden, ook indien de te beschermen bevolking niet medewerkt.

In het volgende zal ik in breede trekken aangeven hoe men naar mijne meening in Suriname tot verbetering van enkele onhygiënische verhoudingen in stad en district zou kunnen geraken.

In de stad Paramaribo is de bestrijding der filariawormziekte, van de boeboeziekte, de matabimba, enz. urgent en nu is het een onomstootbaar feit, dat zonder centrale drinkwatervoorziening eene bestrijding der ziekte onmogelijk is.

De vraag die ons nu gesteld wordt is, hoe komt Paramaribo aan eene centrale watervoorziening.

Een voorziening met regenwater op de gewone thans gebruikelijke manier, zij het ook dat die voorziening wordt verbeterd en gecontroleerd heeft geen zin. In de eerste plaats niet, omdat deze methode duur is, verder is zij niet economisch daar zij geen geld opbrengt en het water niet dienstbaar kan worden gemaakt aan andere hygiënische maatregelen b.v. de faecaalafvoer. Het grootste bezwaar is echter dat trots de verbetering de vorming van muggenbroedplaatsen niet zal worden voorkomen, omdat de niet centrale-watervoorziening noodzakelijkerwijs voeren moet tot het ontstaan van talrijke niet te controleeren muggenbroedplaatsen.

Blijft dus de voorziening door middel van grond- of van oppervlaktewater.

Een grondwatervoorziening zal te kostbaar zijn, daar geschikt grondwater eerst op belangrijken afstand van de stad wordt aangetroffen.

Rest dus de voorziening door middel van rivierwater, waartoe de mogelijkheid bestaat. Het is hier niet de plaats om hierop dieper integaan terwijl wij ons evenmin kunnen verdiepen in beschouwingen over de wijze waarop men aan het benoodigde kapitaal zal kunnen komen. 
Een ding is zeker, zonder offers, zij het dan in vergelijking met de sommen, welke den aanleg der waterleiding vragen zal - nog zoo geringe offers van Paramaribo's bevolking zal eene waterleiding in die stad wel nooit tot stand komen.

Er staat mij hierbij voor den geest de sympathieke geste van de bevolking van Kotta gedang, een kleine stad in de Padangsche bovenlanden, waarvan de bevolking, die leed onder het gebrek aan goed drinkwater, een kleine $f 6000$ bijeenbracht, dat zij der Regeering aanbood als eerste bijdrage voor een te krijgen waterleiding.

Het eerste wat in Paramaribo zal moeten geschieden is een grondig onderzoek door deskundigen. Eene waterleiding is geen philantropisch op te vatten instelling, maar een bedrijf dat zaakkundig moet worden opgezet, commercieel moet worden geleid en zich niet slechts moet kunnen bedruipen, maar ook winst moet afwerpen.

Natuurlijk moeten de voor den aanleg en exploitatie benoodigde sommen worden geleend en zal men voor rentebetaling en aflossing van kapitaal moeten zorgen. Onmogelijk lijkt mij dit niet. Waarom zou het gasbedrijf in $\mathrm{Pa}-$ ramaribo wel en een eventueel aanteleggen en te exploiteeren waterleiding niet rendeeren?

Legt men de Nederlandsche Regeeing goed voorbereide en nauwkeurig becijferde plannen voor, dan zal zij, daar ben ik van overtuigd, hare hulp aan de kolonie welke zij reeds zoo dikwijls bijsprong niet onthouden.

Maar eerst van uit Paramaribo zelf de impuls. Hare bevolking, lijdt onder de filariawormziekte; dat die bevolking zich enkele offers getrooste en een som bijeen trachte te brengen als bijdrage in de kosten welke het vooronderzoek vragen zal. Toont zij op deze wijze haar ernstigen wil om uit hare ellende te geraken, dan zal het Moederland moreel verplicht zijn haar te helpen.

De bestrijding van de ziekten onder de op de ondernemingen arbeidende koeliebevolking is een zuiver plantersbelang. De eigenaren der plantages hebben er in de eerste plaats belang bij, dat zij zooveel mogelijk profijt trekken 
van de dure geïmporteerde arbeidskrachten en het is onbegrijpelijk dat de Surinaamsche planters waaronder men toch genoeg flinke, stoere, wakkere pionniers met ruimen blik aantreft, niet reeds lang naar Deli's voorbeeld de hand aan den ploeg, hier dan aan den hygiënischen ploeg hebben geslagen.

De voorbeelden toch van ondernemingen, die een kwijnend bestaan leden, alleen maar omdat ziekten onder de koelie's den administrateur verhinderden vol pı ofijt van de arbeidskracht der koelies te trekken zijn talrijk.

De voorziening van ondernemingen met arbeidskrachten was voor de Delische planters - vroeger meer dan nu - een even gioot probleem als dit vraagstuk thans voor de Surinaamsche planters vormt.

Een aangeworven en contractueel verbonden koelie vertegenwoordigt een belangrijke som.Op de ondernemingen waren ziekten niet alleen de oorzaak van groote sterfte, maar werd door slepende ziekten als dysenterie en mijnwormziekte de werklust en werkkracht der arbeiders ondermijnd.

Toen het medici als Schüffner en Kuenen gelukte de planters der Deli en Senembah maatschappij te overtuigen, dat het in het belang hunner maatschappijen was voor de bestrijding der koelieziekten gelden beschikbaar te stellen en toen deze medici na hunne reorganisatie van den dienst, de bestrijding begonnen en reeds spoedig op schitterende resultaten konden wijzen, werd de assaineering der arbeidersbevolking met kracht begonnen en doorgezet. Niet alleen nam de belangrijke sterfte af maar ook keerden werklust en werkkracht terug. Andere planters werden reeds spoedig overtuigd van de voordeelen welke Schüffners' systeem ook voor hen kon opleveren en volgden het voorbeeld der beide genoemde maatschappijen. Thans, nog geen 25 jaar na de eerste pogingen van Schüffner, is Sumatra's Oostkust medisch beter dan eenig ander deel van Insulinde verzorgd. Dit resultaat werd bereikt zonder finantieelen steun der Indische Regeering.

In Suriname is men nog ver van dezen idealen toestand verwijderd. 
Men treft er op de ondernemingen dezelfde toestanden aan als vroeger in Deli. Op elke onderneming heeft men een dikwijls zeer primitief en duur hospitaal. De medicus, die deze verschillende hospitaaltjes bezoeken moet, is door het gouvernement aangesteld en wordt niet door de ondernemingen betaald. Wil hij de ondernemingen bereiken dan moet hij het grootste deel van zijn tijd in roei- of motorboot doorbrengen. Hij moet zijn dienst op de ondernemingen zoo gauw mogelijk verrichten,daar hij een uitgestrekt gebied te controleeren heeft en hij alle ondernemingen voor donker moet hebben bezocht.

Het is voor den gouvernementsmedicus door deze dienstregeling absoluut onmogelijk zich met plantage-hygiëne te bemoeien.

Wil men werkelijk de hygiënische wantoestanden op de ondernemingen verbeteren dan moeten de planters samenwerken. Op een of meer geschikt gelegen ondernemingen moet een centraal hospitaal worden gebouwd. Zooveel mogelijk ondernemingen moeten zich daarbij aansluiten en het hospitaal gezamentlijk exploiteeren.

Zulk een hospitaal zou het centraalstation vormen van waaruit de medicus de hygiëne op de ondernemingen controleert en verzorgt. Hoe de fijnere nuanceering der organisatie zal moeten zijn is van hieruit moeilijk te bepalen, misschien zou men het Delisch systeem zonder meer kunnen toepassen, misschien zou men dit systeem moeten wijzigen om het aan de verhoudingen op Surinaamsche ondernemingen te doen aanpassen.

De planters of juister de door hen, desnoods samen met het gouvernement, bezoldigde medici zouden dan zelf de bestrijding der mijnwormziekte, van de dysenterie, malaria enz. tot heil hunner bedrijven ter hand kunnen nemen en spoedig zouden hun, even als vroeger aan hunne Delische collega's, de voordeelen der nieuwe regeling - in een vermeerderde arbeidsprestatie en geringer ziekte- en sterftecijfer hunner koelies blijken. 